\title{
Adaptive evolution of bat dipeptidyl peptidase 4 (dpp4): implications for the origin and emergence of Middle East respiratory syndrome coronavirus
}

\author{
Jie Cui ${ }^{*}$, John-Sebastian Eden ${ }^{1}$, Edward C Holmes ${ }^{1}$ and Lin-Fa Wang ${ }^{2,3}$
}

\begin{abstract}
Background: The newly emerged Middle East respiratory syndrome coronavirus (MERS-CoV) that first appeared in Saudi Arabia during the summer of 2012 has to date (20th September 2013) caused 58 human deaths. MERS-CoV utilizes the dipeptidyl peptidase 4 (DPP4) host cell receptor, and analysis of the long-term interaction between virus and receptor provides key information on the evolutionary events that lead to the viral emergence.

Findings: We show that bat DPP4 genes have been subject to significant adaptive evolution, suggestive of a long-term arms-race between bats and MERS related CoVs. In particular, we identify three positively selected residues in DPP4 that directly interact with the viral surface glycoprotein.
\end{abstract}

Conclusions: Our study suggests that the evolutionary lineage leading to MERS-CoV may have circulated in bats for a substantial time period.

Keywords: MERS-CoV, Bats, Arms-race, Adaptive evolution, Emergence

\section{Main text}

Middle East respiratory syndrome coronavirus (MERS$\mathrm{CoV}$ ) [1], first described by the World Health Organization (WHO) on 23rd September 2012 [2,3], has to date (20th September 2013) caused 130 laboratory-confirmed human infections with 58 deaths (http://www.who.int/csr/ don/2013_09_20/en/index.html). MERS-CoV belongs to lineage $\mathrm{C}$ of the genus Betacoronavirus in the family Coronaviridae, and is closely related to Tylonycteris bat coronavirus HKU4 (BtCoV-HKU4), Pipistrellus bat coronavirus HKU5 (Bt-HKU5) $[4,5]$ and CoVs in Nycteris bats [6], suggestive of a bat-origin [6]. Unlike severe acute respiratory syndrome (SARS) $\mathrm{CoV}$ which uses the angiotensin-converting enzyme 2 (ACE2) receptor for cell entry [7], MERS-CoV employs the dipeptidyl peptidase 4 receptor (DPP4; also known as CD26), and recent work has demonstrated that expression of both human and bat DPP4 in non-susceptible cells enabled viral entry [8].

\footnotetext{
* Correspondence: jiecui@yahoo.com

${ }^{1}$ Marie Bashir Institute for Infectious Diseases and Biosecurity, School of Biological Sciences and Sydney Medical School, The University of Sydney, Sydney, NSW 2006, Australia

Full list of author information is available at the end of the article
}

Cell-surface receptors such as DPP4 play a key role in facilitating viral invasion and tropism. As a consequence, the long-term co-evolutionary dynamics between hosts and viruses often leave evolutionary footprints in both receptor-encoding genes of hosts and the receptor-binding domains (RBDs) of viruses in the form of positively selected amino acid residues (i.e. adaptive evolution). For example, signatures of recurrent positive selection have been observed in $A C E 2$ genes in bats [9], supporting the past circulation of SARS related CoVs in bats. To better understand the origins of MERS-CoV, as well as their potentially long-term (compared to short-term which lacks virus-host interaction) evolutionary dynamics with bat hosts $[5,10]$, we studied the molecular evolution of DPP4 across the mammalian phylogeny.

We first analyzed the selection pressures acting on bat DPP4 genes using the ratio of nonsynonymous $\left(\mathrm{d}_{\mathrm{N}}\right)$ to synonymous $\left(\mathrm{d}_{\mathrm{S}}\right)$ nucleotide substitutions per site (ratio $d_{N} / d_{S}$ ), with $d_{N}>d_{S}$ indicative of adaptive evolution. The complete DPP4 mRNA sequence of the common pipistrelle 
Table 1 Sequences used in the evolutionary analysis of DDP4

\begin{tabular}{|c|c|c|c|}
\hline Common name & Species name & Family & Accession no. \\
\hline Sheep & Ovis aries & Bovidae & XM_004004660 \\
\hline Killer whale & Orcinus orca & Delphinidae & XM_004283621 \\
\hline Cow & Bos taurus & Bovidae & NM_174039 \\
\hline Pig & Sus scrofa & Suidae & NM_214257 \\
\hline Pacific walrus & Odobenus rosmarus divergens & Odobenidae & XM_004410199 \\
\hline Ferret & Mustela putorius furo & Mustelidae & DQ266376 \\
\hline Cat & Felis catus & Felidae & NM_001009838 \\
\hline Horse & Equus caballus & Equidae & XM_001493999 \\
\hline Rhinoceros & Ceratotherium simum & Rhinocerotidae & XM_004428264 \\
\hline Large flying fox & Pteropus vampyrus & Pteropodidae & ENSPVAG00000002634 \\
\hline Black flying fox & Pteropus alecto & Pteropodidae & KB031068 \\
\hline Common vampire bat & Desmodus rotundus & Phyllostomidae & GABZ01004546 \\
\hline Brandt's bat & Myotis brandtii & Vespertilionidae & KE161360 \\
\hline David's myotis & Myotis davidii & Vespertilionidae & KB109552 \\
\hline Little brown bat & Myotis lucifugus & Vespertilionidae & GL429772 \\
\hline Common pipistrelle & Pipistrellus pipistrellus & Vespertilionidae & KC249974 \\
\hline Guinea pig & Cavia porcellus & Caviidae & XM_003478564 \\
\hline Degu & Octodon degus & Octodontidae & XM_004629976 \\
\hline Lesser Egyptian jerboa & Jaculus jaculus & Dipodidae & XM_004651712 \\
\hline Mouse & Mus musculus & Muridae & BC022183 \\
\hline Rat & Rattus norvegicus & Muridae & NM_012789 \\
\hline Human & Homo sapiens & Hominidae & NM_001935 \\
\hline Chimpanzee & Pan troglodytes & Hominidae & GABE01002695 \\
\hline Pygmy chimpanzee & Pan paniscus & Hominidae & XM_003820939 \\
\hline Gorilla & Gorilla gorilla gorilla & Hominidae & XM_004032706 \\
\hline Orangutan & Pongo abelii & Hominidae & NM_001132869 \\
\hline Gibbon & Nomascus leucogenys & Hylobatidae & XM_003266171 \\
\hline Olive baboon & Papio anubis & Cercopithecidae & XM_003907539 \\
\hline Rhesus monkey & Macaca mulatta & Cercopithecidae & JU474559 \\
\hline Galago & Otolemur garnettii & Galagidae & XM_003795172 \\
\hline Marmoset & Callithrix jacchus & Cebidae & XM_002749392 \\
\hline American pika & Ochotona princeps & Ochotonidae & XM_004577330 \\
\hline
\end{tabular}

(Pipistrellus pipistrellus) was downloaded from GenBank (www.ncbi.nlm.nih.gov/genbank/) along with that of the common vampire bat (Desmodus rotundus) from one transcriptome database (http://www.ncbi.nlm.nih.gov/ bioproject/178123). These sequences were then used to mine and extract DPP4 mRNA transcripts from a further five bat genomes (Table 1) using tBLASTn and GeneWise [11]. The complete DPP4 genes of bats and non-bat reference genomes from a range of mammalian species (Table 1) were aligned using MUSCLE [12] guided by translated amino acid sequences $(n=32 ; 727$ amino acids). We then compared a series of models within a maximum likelihood framework [13], incorporating the published mammalian species tree [14-16]. This analysis (the Free Ratio model) revealed that the $\mathrm{d}_{\mathrm{N}} / \mathrm{d}_{\mathrm{S}}$ value on the bat lineage (0.96) was four times greater than the mammalian average (Figure 1). The higher $d_{N} / d_{S}$ ratios leading to bats (Table 2) during mammalian evolution accord with the growing body of data $[5,6,17,18]$ that the newly emerged MERS-CoV ultimately has a bat-origin.

We next analysed the selection pressures at individual amino acid sites in bat DPP4. Using the Bayesian FUBAR 




method [19] in HyPhy package [20], we identified six codons that were assigned $d_{N} / d_{S}>1$ with higher posterior probability (a strict cut-off of $95 \%$ in this analysis) (Table 3). To identify those sites under positive selection that may interact directly with MERS-CoV-like spike protein, bat DPP4 (from the common pipistrelle) was modelled against the structure of the human DPP4/ MERS-CoV spike complex [21] (Figure 2A). This revealed that three of the six positive selected residues (position 187, 288 and 392) were located at the interface between bat DPP4 and MERS-CoV RBD (receptor binding domain) (Figure 2). These residues therefore provide direct evidence of a long-term co-evolutionary history between viruses and their hosts. We also observed several variable regions (Figure $2 \mathrm{~B}$ ) within the bat $\mathrm{RBD}$, that may also have resulted from virally-induced selection pressure and which merit additional investigation in a larger data set.

Our analysis therefore suggests that the evolutionary lineage leading to current MERS-CoV co-evolved with bat hosts for an extended time period, eventually jumping species boundaries to infect humans and perhaps through an intermediate host. As such, the emergence of
Table 2 Numbers of nonsynonymous $\left(d_{N}\right)$ and synonymous $\left(d_{s}\right)$ substitutions per site DPP4 genes in different mammals

\begin{tabular}{|c|c|c|c|}
\hline Common name & $d_{N}$ & $d_{s}$ & $d_{N} / d_{S}$ \\
\hline Sheep & 0.004 & 0.013 & 0.280 \\
\hline Killer whale & 0.023 & 0.039 & 0.595 \\
\hline Cow & 0.003 & 0.016 & 0.157 \\
\hline Pig & 0.027 & 0.109 & 0.246 \\
\hline Pacific walrus & 0.014 & 0.053 & 0.260 \\
\hline Ferret & 0.015 & 0.064 & 0.235 \\
\hline Cat & 0.021 & 0.081 & 0.258 \\
\hline Horse & 0.016 & 0.055 & 0.290 \\
\hline Rhinoceros & 0.017 & 0.044 & 0.385 \\
\hline Large flying fox & 0.005 & 0.001 & 3.561 \\
\hline Black flying fox & 0.004 & 0.008 & 0.487 \\
\hline Common vampire bat & 0.042 & 0.125 & 0.500 \\
\hline Brandt's bat & 0.006 & 0.012 & 0.463 \\
\hline David's myotis & 0.010 & 0.028 & 0.380 \\
\hline Little brown bat & 0.007 & 0.007 & 0.943 \\
\hline Common pipistrelle & 0.031 & 0.066 & 0.470 \\
\hline Guinea pig & 0.018 & 0.078 & 0.238 \\
\hline Degu & 0.016 & 0.128 & 0.122 \\
\hline Lesser Egyptian jerboa & 0.023 & 0.179 & 0.131 \\
\hline Mouse & 0.019 & 0.093 & 0.206 \\
\hline Rat & 0.027 & 0.110 & 0.248 \\
\hline Human & 0.001 & 0.007 & 0.086 \\
\hline Chimpanzee & 0.000 & 0.002 & 0.000 \\
\hline Pygmy chimpanzee & 0.001 & 0.000 & ND \\
\hline Gorilla & 0.003 & 0.004 & 0.863 \\
\hline Orangutan & 0.002 & 0.000 & ND \\
\hline Gibbon & 0.003 & 0.009 & 0.344 \\
\hline Olive baboon & 0.000 & 0.005 & 0.000 \\
\hline Rhesus monkey & 0.000 & 0.004 & 0.000 \\
\hline Galago & 0.022 & 0.149 & 0.149 \\
\hline Marmoset & 0.009 & 0.053 & 0.160 \\
\hline American pika & 0.036 & 0.229 & 0.156 \\
\hline
\end{tabular}

ND: Not determined because no synonymous substitutions are present.

Table 3 Putatively positive selected DPP4 codons in bats

\begin{tabular}{lll}
\hline Codon position $^{a}$ & Posterior probability $^{b}$ & $\mathbf{d}_{\mathbf{N}} / \mathbf{d}_{\mathbf{s}}$ \\
\hline 46 & 0.97 & 14.95 \\
57 & 0.97 & 13.13 \\
112 & 0.94 & 10.27 \\
187 & 0.95 & 8.55 \\
288 & 0.98 & 13.90 \\
392 & 0.97 & 14.63
\end{tabular}

${ }^{a}$ Codon position corresponding to the human DPP4 (NP_001926) protein sequence. ${ }^{b}$ Posterior probability of residues assigned a $d_{N} / d_{S}$ ratio greater than 1 . 


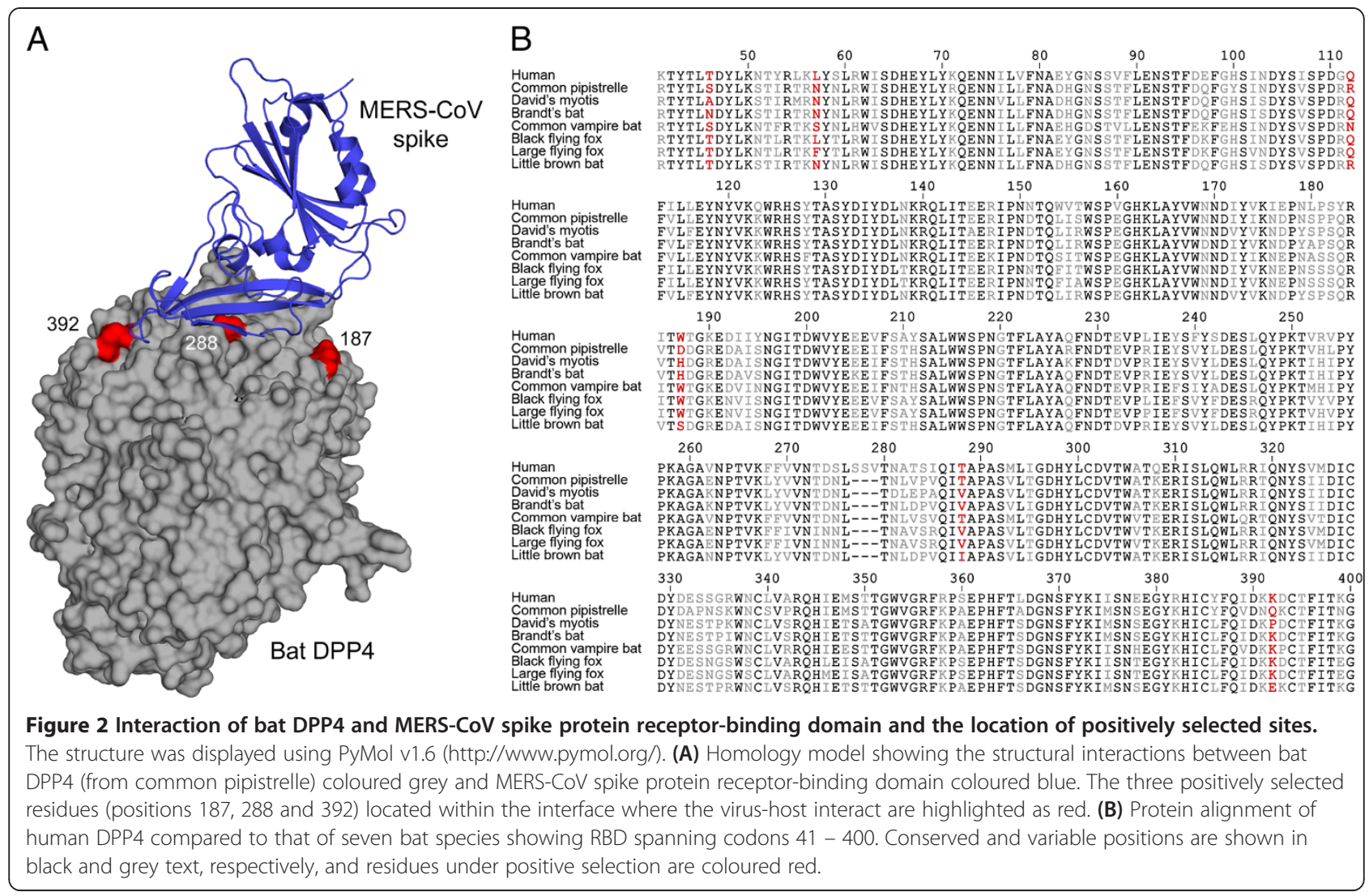

MERS-CoV may parallel that of the related SARS-CoV [22]. Although one bat species, Taphozous erforatus, in Saudi Arabia has been found to harbour a small $R d R p$ (RNA-Dependent RNA Polymerase) fragment of MERS$\mathrm{CoV}$ [17], a larger viral sampling of bats and other animals with close exposure to humans, including dromedary camels were serological evidence for MERS-CoV has been identified [23], are clearly needed to better understand the viral transmission route. Alternatively, it is possible that the adaptive evolution present on the bat DPP4 was due to viruses other than MERS-CoVs, and which will need to be better assessed when a larger number of viruses are available for analysis. Overall, our study provides evidence that a long-term evolutionary arms race likely occurred between MERS related CoVs and bats.

\section{Competing interests}

The authors declare that they have no competing interests.

\section{Authors' contributions}

JC and LFW designed the research. JC and JSE analysed the data. JC and ECH drafted the manuscript. All authors read and approved the final manuscript.

\section{Acknowledgements}

We thank Christopher Cowled at CSIRO Australian Animal Health Laboratory for annotating the Pterous aleco DPP4. This word was supported in part by a grant from the National Research Foundation, Singapore (NRF2012NRF-CRP001-056) and the CSIRO Office of the Chief Executive Science Leaders Award. ECH is supported by an NHMRC Australia Fellowship.

\section{Author details}

'Marie Bashir Institute for Infectious Diseases and Biosecurity, School of Biological Sciences and Sydney Medical School, The University of Sydney, Sydney, NSW 2006, Australia. ${ }^{2}$ Duke-NUS Graduate Medical School, Singapore 169857, Singapore. ${ }^{3}$ CSIRO Livestock Industries, Australian Animal Health Laboratory, Geelong, VIC 3220, Australia.

Received: 3 September 2013 Accepted: 3 October 2013 Published: 10 October 2013

\section{References}

1. de Groot RJ, Baker SC, Baric RS, Brown CS, Drosten C, Enjuanes L, Fouchier RA, Galiano M, Gorbalenya AE, Memish ZA, Perlman S, Poon LL, Snijder EJ, Stephens GM, Woo PC, Zaki AM, Zambon M, Ziebuhr J: Middle East respiratory syndrome coronavirus (MERS-CoV): announcement of the coronavirus study group. J Virol 2013, 87:7790-7792.

2. Zaki AM, van Boheemen $S$, Bestebroer TM, Osterhaus AD, Fouchier RA: Isolation of a novel coronavirus from a man with pneumonia in Saudi Arabia. N Engl J Med 2012, 367:1814-1820.

3. Bermingham A, Chand MA, Brown CS, Aarons E, Tong C, Langrish C, Hoschler K, Brown K, Galiano M, Myers R, Pebody RG, Green HK, Boddington NL, Gopal R, Price N, Newsholme W, Drosten C, Fouchier RA, Zambon M: Severe respiratory illness caused by a novel coronavirus, in a patient transferred to the United Kingdom from the Middle East, September 2012. Euro Surveill 2012, 17:20290.

4. van Boheemen S, de Graaf M, Lauber C, Bestebroer TM, Raj VS, Zaki AM, Osterhaus AD, Haagmans BL, Gorbalenya AE, Snijder EJ, Fouchier RA: Genomic characterization of a newly discovered coronavirus associated with acute respiratory distress syndrome in humans. mBio 2012, 3:e00473-12.

5. Lau SK, Li KS, Tsang AK, Lam CS, Ahmed S, Chen H, Chan KH, Woo PC, Yuen KY: Genetic characterization of Betacoronavirus lineage $C$ viruses in bats reveals marked sequence divergence in the spike protein of Pipistrellus bat coronavirus HKU5 in Japanese Pipistrelle: implications 
for the origin of the novel Middle East respiratory syndrome coronavirus. J Virol 2013, 87:8638-8650.

6. Annan A, Baldwin HJ, Corman VM, Klose SM, Owusu M, Nkrumah EE, Badu EK, Anti P, Agbenyega O, Meyer B, Oppong S, Sarkodie YA, Kalko EK, Lina PH, Godlevska EV, Reusken C, Seebens A, Gloza-Rausch F, Vallo P, Tschapka M, Drosten C, Drexler JF: Human betacoronavirus 2c EMC/2012-related viruses in bats, Ghana and Europe. Emerg Infect Dis 2013, 19:456-459.

7. Müller MA, Raj VS, Muth D, Meyer B, Kallies S, Smits SL, Wollny R, Bestebroer TM, Specht S, Suliman T, Zimmermann K, Binger T, Eckerle I, Tschapka M, Zaki AM, Osterhaus AD, Fouchier RA, Haagmans BL, Drosten C: Human coronavirus EMC does not require the SARS-coronavirus receptor and maintains broad replicative capability in mammalian cell lines. mBio 2012, 3:e00515-12.

8. Raj VS, Mou H, Smits SL, Dekkers DH, Müller MA, Dijkman R, Muth D, Demmers JA, Zaki A, Fouchier RA, Thiel V, Drosten C, Rottier PJ, Osterhaus AD, Bosch BJ, Haagmans BL: Dipeptidyl peptidase 4 is a functional receptor for the emerging human coronavirus-EMC. Nature 2013, 495:251-254.

9. Demogines A, Farzan M, Sawyer SL: Evidence for ACE2-utilizing coronaviruses (CoVs) related to severe acute respiratory syndrome $\mathrm{CoV}$ in bats. J Virol 2012, 86:6350-6353.

10. Kindler $E$, Jónsdóttir HR, Muth D, Hamming OJ, Hartmann R, Rodriguez R, Geffers R, Fouchier RA, Drosten C, Müller MA, Dijkman R, Thiel V: Efficient replication of the novel human betacoronavirus EMC on primary human epithelium highlights its zoonotic potential. mBio 2013, 4:e00611-e00612.

11. Birney E, Clamp M, Durbin R: GeneWise and Genomewise. Genome Res 2004, 14:988-995.

12. Edgar RC: MUSCLE: multiple sequence alignment with high accuracy and high throughput. Nucleic Acids Res 2004, 32:1792-1797.

13. Yang Z: PAML 4: phylogenetic analysis by maximum likelihood. Mol Biol Evol 2007, 24:1586-1591.

14. Murphy WJ, Pevzner PA, O'Brien SJ: Mammalian phylogenomics comes of age. Trends Genet 2004, 20:631-639.

15. Teeling EC, Springer MS, Madsen O, Bates P, O'brien SJ, Murphy WJ: A molecular phylogeny for bats illuminates biogeography and the fossil record. Science 2005, 307:580-584.

16. Perelman $P$, Johnson WE, Roos $C$, Seuánez HN, Horvath JE, Moreira MA, Kessing B, Pontius J, Roelke M, Rumpler Y, Schneider MP, Silva A, O'Brien SJ, Pecon-Slattery J: A molecular phylogeny of living primates. PLoS Genet 2011, 7:e1001342.

17. Memish ZA, Mishra N, Olival KJ, Fagbo SF, Kapoor V, Epstein JH, AlHakeem R, Al Asmari M, Islam A, Kapoor A, Briese T, Daszak P, Al Rabeeah AA, Lipkin WI: Middle east respiratory syndrome coronavirus in bats, Saudi Arabia. Emerg Infect Dis. in press.

18. Ithete NL, Stoffberg S, Corman VM, Cottontail VM, Richards LR, Schoeman MC, Drosten C, Drexler JF, Preiser W: Close relative of human middle East respiratory syndrome coronavirus in bat, South Africa. Emerg Infect Dis 2013, 19:1697-1699.

19. Murrell B, Moola S, Mabona A, Weighill T, Sheward D, Kosakovsky Pond SL, Scheffler K: FUBAR: a fast, unconstrained bayesian approximation for inferring selection. Mol Biol Evol 2013, 30:1196-1205.

20. Pond SL, Frost SD, Muse SV: HyPhy: hypothesis testing using phylogenies. Bioinformatics 2005, 21:676-679.

21. Wang N, Shi X, Jiang L, Zhang S, Wang D, Tong P, Guo D, Fu L, Cui Y, Liu X, Arledge $K C$, Chen YH, Zhang L, Wang X: Structure of MERS-CoV spike receptor-binding domain complexed with human receptor DPP4. Cell Res 2013, 23:986-993.

22. Cui J, Han N, Streicker D, Li G, Tang X, Shi Z, Hu Z, Zhao G, Fontanet A, Guan $Y$, Wang L, Jones G, Field HE, Daszak P, Zhang S: Evolutionary relationships between bat coronaviruses and their hosts. Emerg Infect Dis 2007, 13:1526-1532
23. Reusken CB, Haagmans BL, Müller MA, Gutierrez C, Godeke GJ, Meyer B, Muth D, Raj VS, Vries LS, Corman VM, Drexler JF, Smits SL, El Tahir YE, De Sousa R, van Beek J, Nowotny N, van Maanen K, Hidalgo-Hermoso E, Bosch BJ, Rottier P, Osterhaus A, Gortázar-Schmidt C, Drosten C, Koopmans MP: Middle East respiratory syndrome coronavirus neutralising serum antibodies in dromedary camels: a comparative serological study. Lancet Infect Dis 2013, 13:859-866.

doi:10.1186/1743-422X-10-304

Cite this article as: Cui et al:: Adaptive evolution of bat dipeptidyl peptidase 4 (dpp4): implications for the origin and emergence of Middle East respiratory syndrome coronavirus. Virology Journal 2013 10:304.

\section{Submit your next manuscript to BioMed Central and take full advantage of:}

- Convenient online submission

- Thorough peer review

- No space constraints or color figure charges

- Immediate publication on acceptance

- Inclusion in PubMed, CAS, Scopus and Google Scholar

- Research which is freely available for redistribution

Submit your manuscript at www.biomedcentral.com/submit
C Biomed Central 